\title{
Equivalence of Festival Culture from Cultural Perspective
}

\author{
Dr. Linli Chen \\ Associate Professor \\ School of Cultural Tourism and International Exchange \\ Yunnan Open University \\ 113 Xuefu Road, Kunming 650223, China
}

\begin{abstract}
Equivalence, as one of the most controversial and problematic issues in translation studies for centuries, can be said to be the central issue in translation that aims at conveying meaning from one language to another. Eugene A. Nida, with his theory "dynamic equivalence", has provided theoretical foundation for further study in this field. There are many factors, such as linguistics, culture and expertise knowledge in certain fields influencing the process of translating and a complete equivalence is, in most cases, hardly possible. Therefore, it is important to have the translator's cultural awareness and creativity in translating based on certain translation theories. In this paper, equivalence of festival Culture of ethnic group in China from cultural perspective will be discussed, trying to find future directions for further research on this topic.
\end{abstract}

Keywords: Culture, equivalence, festival culture, translation

\section{Introduction}

Sapir says, "Culture may be defined as what a society does and thinks. Language is a particular how of thought" (E. Sapir, 1921). Benedict says in her book Patterns of Culture: "What really binds men together is their culture -- the ideas and the standards they have in common" (R. Benedict, 1935). E. B. Taylor defines culture as "a complex whole which includes knowledge, beliefs, art, morals, law, custom and any other capabilities and habits acquired by individuals as members of a society." (E. B. Taylor, 1871).

Culture is often compared to an iceberg to imply that only a small part (some say ten percent) of it is visible while most of it is not. It is important to know this in our discussion of festival culture, for it helps us better understand the problems involved.

It needs no explanation that a great deal of difference can be perceived between people from different countries even in food, clothing and housing, etc. Hence a number of words characteristic of national flavors. Of course, the rendering of words characteristic of national flavors is not so much a matter of logic as that of usage. Actually many versions follow no logic at all. It is true that no one devoid of imaginative flexibility could make satisfactory rendering. It is equally important that there must be no lack of scientific approach to translation, including the translation of words characteristic of national flavors.

\section{About Equivalence}

Those who work on translation theories have written on issues of equivalence and non-equivalence of words and phrases across languages.

What is the meaning of equivalence? The Random House Dictionary gives "equal" as being derived, via Middle English, from the Latin "aequalis," meaning "equal, like." And the meaning of equivalence can be described as "equal in value, measure, force, effect, significance."

The term "equivalence" in translation first appeared in J. R. Firth's writing (1957) when he stated that "the so-called translation equivalents between two languages are never really equivalent" (Snell-Hornby, 1988, p. 37). With the development of linguistics and the study of translation in the 1960s, "translation equivalence" became the focus of study in linguistic-oriented western translation theories (Ma, 2003, p. 87). 
Since the late 1950s "translation equivalence" has been discussed as a central issue in western translation studies. Catford defined translation as "the replacement of textual material in one language (SL) by equivalent textual material in another language (TL)" (1965, p. 27). Nida and Otto Kade adopted a communicative approach to translation equivalence. Nida's "dynamic equivalence" was to communicate effectively the source language message, namely, to reproduce "the closest natural equivalent" to the source-language message in the receptor language (Nida \& Taber, 1969, p. 12).

The term "equivalence" has aroused a lot of controversies among translation scholars because it is also used in mathematics and other sciences as a technical term indicating "a relationship of absolute symmetry". Some hold that it is not appropriate to adopt the concept of equivalence in the study of translation. For instance, James Holmes argues that no translation is ever "the same" as or "equivalent" to its original, and considers the term "equivalence" perverse since "to ask for sameness is to ask too much" (Bassnett, 1980). Snell-Hornby (1988) asserts that "the term equivalence presents an illusion of symmetry between languages and is unsuitable as a basic concept in translation theory".

\section{Equivalence of Festival Culture}

In Nida's theory, "dynamic equivalence" is defined with "receptors' response" as its nature. Unlike traditional translation theories, which focus on verbal comparison between the original text and its translation, Nida's concept of translating shifts from "the form of the message" to "the response of the receptor". In Nida's view, when determine whether a translation is faithful to the original text or not, the critic should not compare the formal structures between the source text and its translation, but compare "receptors' response" (Ma, 2003, p. 19). That is to say, the critic should judge a translation by seeing how the receptor, for whom the translated text is intended, reacts to it, not by verbal correspondence between the two texts in question.

It is cultural differences, language and cultural barriers, various historical backgrounds and social customs that make dynamic equivalence complex. Biculturalism is even more important than bilingualism for truly successful understanding and translating, since words or idioms only have meanings in terms of the cultures in which they function, Eugene A. Nida once pointed out. Only by being in the countries in which a foreign language is spoken can one acquire the necessary sensitivity to the many special meanings of words and phrases. Some of the difficulties of translation stem from culturally idiosyncratic meanings. A text which only reflects the many concepts and literary canons of a particular isolated culture often includes information which is extremely difficult to understand and to translate in a distinct language-culture (Nida, 2001, p. 84).

A good command of cultural information is essential for accurate translation, especially for ethnic cultural words. Thorough understanding of ethnic culture is the basis of dynamic equivalence translations. There are various ethnic cultures in China. In terms of festival culture, various cultural words and background information make its understanding uneasy.

\subsection{Spring Festival}

For Han, the most important Chinese festival is the Spring Festival, also known as the Chinese New Year. To the Chinese people it is as important as the Christmas to people in the West. The dates for this annual celebration are determined by the lunar calendar rather than the Gregorian calendar, so the timing of the holiday varies from late January to early February. "Guo Nian," which means "passing the year," is the common term among the Chinese people for celebrating the Spring Festival. It actually means greeting the New Year. At midnight at the turn of the old and new year, people used to let off firecrackers which serve to drive away the evil spirits and to greet the arrival of the new year. In an instant the whole city would be engulfed in the deafening noise of the firecrackers. On New Year's Eve, all the members of the families come together to feast. Jiaozi, a steamed dumpling, is popular in the north, while southerners favor a sticky sweet glutinous rice pudding called nian gao. It is hard for people to understand and translate some of the cultural words only if one is both bilingual and bicultural and always remember that translation is not the transferring process of language but of culture. 


\subsection{Water-Splashing Festival}

For the Dai, the De'ang and the Achang nationalities in Yunnan, China, the Water-Splashing Festival is their traditional festival. It is called "Len He Sang Kan" in Dai language, meaning "the New Year's Day in June". The festival is usually celebrated in late June or early July on the Dai calendar (mid April of the Gregorian calendar), and is the New Year's Day on the Dai calendar, which is also as important as the Christmas celebration to people in the West. The festival lasts for three days. The main activities include dragon-boat racing, fireworks setting off, water splashing, fair going and cloth-bundle throwing. The De'ang and the Achang people have their own ways to celebrate this festival, offering and accepting benediction. (Song, 2007, p. 73)

\subsection{Kuoshi Festival}

The "Kuoshi" festival, the Lisu New Year, is the biggest festival among the Lisu nationalities in Yunnan. Regions different, the time of celebration also differs. But generally, the festival lasts from the $5^{\text {th }}$ day of $12^{\text {th }}$ lunar month to $10^{\text {th }}$ day of $1^{\text {st }}$ lunar month, a period the Lisu people also call "the Month of Celebration". During the festival, religious activities of offering sacrifices will be carried out and such amusements as crossbow shooting, dancing, catapulting, pole climbing and antiphonal-style singing will be held (Song, 2007, p. 115). It is not easy for those who are unfamiliar with this kind of culture to understand and translate the related cultural words, but only keep in mind one thing that translation is more about the transferring process of culture.

\subsection{Danian}

Danian, "Wuxi" in the Pumi language, is the most lively and most ceremonious festival among the Pumi people in Yunnan, which is as important as the celebration of Chinese New Year to the Han people in China, but with much different celebrating activities. The celebration usually starts from the first or second ten days of $12^{\text {th }}$ lunar year. On the first day of $1^{\text {st }}$ lunar month, people will fire to the sky to welcome the coming of the New Year. In the daytime, they will shoot at targets, have horseracing, go swinging and sing antiphonal songs. At night, they will dance and sing. (Song, 2007, p. 265)

\subsection{Kaquewa Festival}

"Kaquewa" Festival is the only New Year Festival of Dulong Nationality in Yunnan. It is held during the eleventh and twelfth lunar months. There is no fixed date and the festival lasts 3 to 5 days. It is as important as the Chinese New Year to the Han people in China and the Christmas to people in the West. On the first day of the festival, every family hangs up colored tapestry as festive decoration. The second day is devoted to honoring the mountain god. They make images of the mountain god and many wild animals with the dough of buckwheat flour. When the ceremony of honoring the mountain god is over, young archers shoot the dough-made animals. On the last day, they hold the most exciting activity - killing and sacrificing an ox. They keep drinking, singing and dancing until they enjoy themselves to their hearts' content. (Song, 2007, p. 326)

It is hard to translate the festival cultures accurately if the translator is unfamiliar with the culture of ethnic people. To have cultural awareness in translating is important. It is the translated language through which its beliefs are expressed and transmitted and by which most interaction of its members takes place. The translation strategy used to render the sense of ethnic cultural words and culture here are in accord with Nida's principle of meaning with priority in translating. And word-for-word translation can be avoided. This is also in line with Nida's "dynamic equivalence", which stresses that translating is to communicate efficiently the meaning to the intended reader in the receptor language.

\section{Conclusion}

Many factors should be taken into consideration while translating because it involves both different cultures and various situations. Translating is a complex and fascinating task. Translation study is a discipline related to the study of the theory and phenomena of translation, and it is multilingual and also interdisciplinary, encompassing languages, linguistics, communication studies, philosophy and a range of cultural studies. "Various theories have validity for various aspects of physical and behavioral phenomena, and no one theory can explain everything... 
Accordingly, a translator should take full advantage of the significant contributions which have been made by scholars employing quite different theories about interlingual communication.” (Nida, 1986, p. 185).

The task of translation theory is to study translation problems, no translation problem, no translation theory (Newmark, 1998). Translation problems encountered by scholars either in China or in western countries may have something in common, although different translation theories may have their own deficiencies and limitations resulting from diverse social and cultural backgrounds, various psychological structures of the nationality and different objectives of study. Appropriate option of translation theory makes the gap between different cultures including ethnic cultures narrow and makes cultural exchange among countries more possible, convenient and easier. It is believed that, with more cultural considerations, further research and more explorations in this field are still necessary and worthy.

\section{References}

Benedict, R. (1934). Patterns of Culture. Boston: Houghton Mifflin \& Company.

Budick, Sanford and Wolfgang Iser. (1999). The Translatability of Cultures. California: Stanford University Press.

Catford, J. C. (1965). A Linguistic Theory of Translation. London: Oxford University Press.

Chen Linli. (2018). The Application of Dynamic Equivalence in Translation of Ethnic Culture. International Journal of Language and Linguistics, Vol. 5, No 2, 74-77.

Chen Linli. (2010). On Integrated Translation Approach of English Idioms. Journal of Language Teaching and Research, Vol. 1, No 3, 227-230.

Chen Linli. (2009). On Literal Translation of English Idioms. English Language Teaching, Vol.2, No.2, 164-166.

Chen Linli. (2007). On the Chinese Translation of English Idioms [D]. Shanghai: Shanghai International Studies University.

Gentzler, E. (1993). Contemporary Translation Theories. London and New York: Routledge.

Kumaravadivelu, B. (2008). Culture Globalization and Language Education. New Haven: Yale University Press.

Ma Huijuan. (2003). A Study on Nida's Translation Theory. Beijing: Foreign Language Teaching and Research Press.

Newmark, Peter. (1981). Approaches to Translation. Oxford: Pergmon Press.

Nida, Eugene. A. (1964). Towards a Science of Translating. Brill. Leiden.

Nida, Eugene. A. (1993). Language, Culture, and Translating. Shanghai: Shanghai Foreign Language Education Press.

Nida, Eugene.A. (2002). Language and Culture: Contexts in Translating. Shanghai: Shanghai Foreign Language Education Press.

Nida, Eugene. A. (1986). From one Language to Another. Shanghai: Shanghai Foreign Language Education Press.

Nida, Eugene. A. and C. Taber (1969). The Theory and Practice of Translation. Leiden: E. J. Brill.

Sapir, E. (1956). Culture, Language and Personality. Los Angeles: University of California Press.

Snell-Hornby, Mary. (1988). Translation Studies: An Integrated Approach. Amsterdam: John Benjamins.

Song Liying. (2007). Indigenous Ethnic Groups in Yunnan. Kunming: Yunnan University Press.

Spencer-Oatey, H. (2000). Culturally Speaking. London: Continuum.

Tymoczko, T. (1978). "translation and meaning," in Meaning and Translation: Philosophical and Linguistic Approaches. F. Guenthner \& Guenthner-Reutter, (Eds.). New York: New York University Press.

Venuti, L. (1995).The Translator's Invisibility -- A History of Translation. London and New York: Routledge.

Whorf, B. L. (1956). Language, Thought, and Reality: Selected Writings of Benjamin Lee Whorf. ED. John B. Carroll. Cambridge, MA: MIT Press.

Wilss, W. (1982). The Science of Translation: Problems and Methods. Gunter Narr verlag: Tübingen. 